\title{
Productive performance of dairy cows fed with hydrolyzed sugarcane
}

\section{Desempenho produtivo de vacas leiteiras alimentadas com cana-de-açúcar hidrolisada}

\author{
Donizeti Teixeira Junior ${ }^{\mathrm{I}}$ Regis Luis Missio ${ }^{\mathrm{II}}$ Mariana Paula Rossi Sforcini ${ }^{\mathrm{I}}$ \\ Mauro Dal Secco de Oliveira ${ }^{\mathrm{II}}$ Viviane Borba Ferrari ${ }^{\mathrm{IV}}$ Rafael Ferreira Santos ${ }^{\mathrm{IV}}$
}

\section{ABSTRACT}

This study aimed to evaluate the productive performance of dairy cows fed with sugarcane treated with $5 \mathrm{~g} \mathrm{~kg}^{-1}$ of calcium oxide $(\mathrm{CaO})$ or hydroxide $\left[\mathrm{Ca}(\mathrm{OH})_{2}\right]$. Eight Holstein cows with $638.01 \pm 12.52 \mathrm{~kg}$ of body weight and milk yield of $20.32 \pm 1.5 \mathrm{~kg}$ $d^{-1}$ were randomly assigned into two $4 x 4$ Latin squares, fed with the following diets composed of corn silage (CS), fresh sugarcane (FS), sugarcane treated with calcium oxide (STCO) or calcium hydroxide (STCH) as only forage. Data collection lasted five days, after 15 days of adaptation to diets and facilities. The dry matter intake (\% of body weight) was higher in diets with CS (3.08) compared to those with FS (2.67), STCO (2.73) or STCH (2.73), which did not differ. Diets with CS determined milk production adjusted for $4 \%$ fat $\left(20.05 \mathrm{~kg} \mathrm{~d}^{-1}\right)$ similar to diets containing STCO and STCH (18.01 and $17.89 \mathrm{~kg} \mathrm{~d}^{-1}$, respectively) and higher than those with FS $\left(17.33 \mathrm{~kg} \mathrm{~d}^{-1}\right)$. The experimental diets did not alter the composition of milk. The use of sugarcane treated with $\mathrm{Ca}(\mathrm{OH})_{2}$ is a viable option for feeding Holstein cows with average genetic potential for milk production because it allows production and composition similar to milk dairy cows fed with corn silage, besides benefiting the logistics of feeding in the rural properties.

Key words: hydrated lime, hydrolysis, milk fat, nutrient intake, quicklime.

\section{RESUMO}

Objetivou-se avaliar o desempenho produtivo de vacas leiteiras alimentadas com cana-de-açucar tratada com $5 \mathrm{~g}$ $\mathrm{kg}^{-1}$ de óxido (CaO) ou hidróxido de cálcio $\left[\mathrm{Ca}(\mathrm{OH})_{2}\right]$. Foram utilizadas oito vacas da raça Holandesas com $638,01 \pm 12,52 \mathrm{~kg}$ de peso corporal e produção média de leite de $20,32 \pm 1,5 \mathrm{~kg}$ dia $^{-1}$, distribuidas aleatoriamente em dois quadrados latinos balanceados $4 \times 4$, alimentadas com dietas contendo silagem de milho (SM), cana-de açúcar in natura (CIN), cana-de-açúcar tratada com óxido de cálcio (CTOC) ou hidróxido de cálcio
(CTHC) como único volumoso. O período de coleta de dados foi de cinco dias, após 15 dias de adaptação às instalações e dietas. $O$ consumo de matéria seca (\% do peso corporal) foi superior nas dietas com $\operatorname{SM}(3,08)$ em relação àquelas com $\operatorname{CIN}(2,67)$, CTOC (2,73) ou CTHC (2,73), as quais não diferiram entre si. Dietas com SM determinaram produção de leite ajustada para $4 \%$ de gordura $\left(20,05 \mathrm{~kg} \mathrm{dia}^{-1}\right)$, similar às dietas contendo CTOC e CTHC $\left(18,01\right.$ e 17,89kg dia ${ }^{-1}$, respectivamente) e superior àquelas com $\operatorname{CIN}\left(17,33 \mathrm{~kg} \mathrm{dia}^{-1}\right)$. As dietas experimentais não alteraram a composição do leite. A utilização da cana-de-açúcar tratada com $\mathrm{Ca}(\mathrm{OH})$, é uma alternativa alimentar viável para vacas Holandesas com potencial genético médio para produção leiteira, já que possibilita produção e composição do leite similar à vacas alimentadas com silagem de milho, além de beneficiar a logística de alimentação nas propriedades rurais.

Palavras-chave: cal hidratada, cal virgem, consumo de nutrientes, gordura do leite, hidrólise.

\section{INTRODUCTION}

The sugarcane is a cosmopolitan culture, easy to grow, providing high production of dry matter at low costs, which has been important to be chosen as forage for dairy cows in order to reduce costs with hay and silage. Moreover, sugarcane time of harvest coincides with low production of tropical pastures, favoring its use as forage during dry season. However, this material has low mineral and protein contents and high indigestible fiber, which limits dry matter intake (MAGALHÃES et al., 2004). Moreover, the fresh sugarcane supply for dairy cows requires the

IPrograma de Pós-graduação em Zootecnia, Universidade Estadual Paulista “Júlio de Mesquita Filho” (Unesp), Jaboticabal, SP, Brasil . "Universidade Tecnológica Federal do Paraná (UTFPR), 85503-390, Pato Branco, PR, Brasil. E-mail: regisluismissio@gmail.com. Corresponding author. IIIUnesp, Jaboticabal, SP, Brasil.

${ }^{\text {IV }}$ Departamento de Zootecnia, Unesp, Jaboticabal, SP, Brasil. 
daily cut, undermining the logistics of feeding in the rural properties (MISSIO et al., 2012).

According to the potential as ruminant feed, as well as limitations of its use, recently the amount of research about sugarcane has been intensified aiming to improve the nutritional characteristics and decrease cut frequency of this material by treating with alkalizing agents (DIAS et al., 2011; MISSIO et al., 2012). The use of limes microprocessor enables increased storage time of sugarcane due to the improvement in aerobic stability of hydrolyzed sugarcane in relation to fresh sugarcane (DOMINGUES et al., 2011) and enable increased digestibility of the fiber fraction of forage (PIRES et al., 2010), which can benefit the production of milk (ALVES et al., 2010).

Despite the increasing number of studies with cased limes, the results related to the use of hydrolyzed sugarcane in dairy cow diet are still inconsistent. Thus, the aim of this study was to evaluate yield and milk composition of dairy cows fed with sugarcane treated with calcium oxide $(\mathrm{CaO})$ or hydroxide $\left[\mathrm{Ca}(\mathrm{OH})_{2}\right]$.

\section{MATERIAL AND METHODS}

It was used eight Holstein cows, second and third order of birth, from 40 to 135 days of lactation, average of $638,01 \pm 12.52 \mathrm{~kg}$ body weight and average milk yield of $20.32 \pm 1.5 \mathrm{~kg} \mathrm{~d}^{-1}$. The animals were designed according to milk yield in two $4 \times 4$ Latin squares (four treatments and four periods). The tested diets were composed of corn silage (CS), fresh sugarcane (FS), sugarcane treated with calcium oxide (STCO) or calcium hydroxide (STCH) as only forage. Data collection lasted five days after 15 days of adaptation to the facilities and diets, completing 80 days.

Animals were kept in Tie Stall system, provided with concrete floor, water and feed troughs. The body weight was obtained by weighing tape (mean of three measurements) on fifteenth day of each period, preceding the first meal. Animals were fed ad libitum, allowing $10 \%$ orts, provided twice daily (08h and 16h). Feed intake was measured daily by weighing the feed and orts from the previous day. The concentrate (Table 1) was fixed in one $\mathrm{kg}$ for each three $\mathrm{kg}$ of milk, according to milk yield before the experiment, being mixed with the forage immediately after supplying.

The hybrid corn used for silage was the AG5011, cut at $20 \mathrm{~cm}$ from the ground, $36 \%$ of grain in dry matter (DM). The sugarcane used was cv. 'RB 855536', aged 10-12 months, chopped in a forage machine set to provide $8-10 \mathrm{~mm}$ particles. After chopped, sugarcane was spread in $20 \mathrm{~cm}$ layers on a concrete floor under a shed and a solution of lime were added using a watering can. The solution was prepared with $0.5 \mathrm{~kg}$ of virgin or hydrated lime in 2 liters of water $100 \mathrm{~kg}^{-1}$ of sugarcane (OLIVEIRA, 2010). After homogenization of lime solution with sugarcane, the material concentration in heaps $(500 \mathrm{~kg}, 80 \mathrm{~cm})$ was performed and stored for at least eight hours and maximum of 48 hours before its supply. The fresh sugarcane, on the other hand, was provided immediately after chopping.

Virgin lime contains $72 \% \quad \mathrm{Ca}(\mathrm{OH})_{2}$ and $0.5 \% \mathrm{MgO}$, determining $92 \%$ of total $\mathrm{CaO}$ (hydrolyzing agent). Hydrated presents $95.5 \%$ of $\mathrm{Ca}(\mathrm{OH})_{2}$ and $1.5 \% \mathrm{MgO}$, with $72.5 \%$ of total $\mathrm{CaO}$. The remaining components of the virgin and hydrated limes, 27.5 and $3 \%$ respectively of their composition, are not identified by the producer.

Feed and ort samples were collected in the last five days of each experimental period, predried in a forced air ventilation oven at $55^{\circ} \mathrm{C}$ for 72 hours and ground in a Willey mill equipped with $1 \mathrm{~mm}$ diameter sieves. The dry matter, mineral matter (MM), ether extract (EE) and crude protein (CP) were determined by AOAC (1995). The content of neutral detergent fiber (NDF) was determined according to VAN SOEST et al. (1991). The levels of acid detergent fiber and lignin were determined according to VAN SOEST (1973). The content of total carbohydrates (TC) and non-fiber carbohydrates (NFC) was determined according to SNIFFEN et al. (1992): $\mathrm{TC}=100-(\mathrm{CP}+\mathrm{EE}+\mathrm{MM})$ and $\mathrm{NFC}=\mathrm{TC}-$ NDF. The content of total digestible nutrients (TDN), organic matter digestibility (OMD) and digestibility of neutral detergent fiber (NDFD) were determined according to WEISS (1993): $T D N=($ DCPap $x$ $\mathrm{CP})+(2.25 \mathrm{xEE})+[0.98 \quad \mathrm{x} \quad(100-\mathrm{NDFn}-\mathrm{CP}-$ AshesEE- 1) $]+0.75 \quad \mathrm{x}\{($ NDFn-lignin $) \quad \mathrm{X} \quad[1-($ lignin/ NDFn $\left.\left.)^{0.667}\right]\right\}-7, \quad$ OMD $=($ DCPap $x \quad C P)+($ EE $x$ $2.25)+[0.98 x(100-N D F n-C P-A s h e s-E E-1)]+0.75 \quad x$ $\left\{(\right.$ NDFn-lignin $\left.) \times\left[1-(\text { lignin/NDFn })^{0.667}\right]\right\} /(100-\mathrm{MM})$ x $100, \mathrm{NDFD}=\{[0.75 \times$ (NDFn-lignin) $] \times$ [1-(lignin/ FDNn $\left.\left.)^{0.667}\right] / \mathrm{NDFn}\right\} \times 100$, where: DCPap is digestible crude protein from roughage $(\mathrm{Y}=\mathrm{e}-0.012 \times \mathrm{ADICP})$ and concentrate $(\mathrm{Y}=1-0.004 \times \mathrm{ADICP})$; NDFn=NDF set to nitrogen as determined from protein in neutral detergent of NDF residue $\{\mathrm{ADICP}=$ $8.77+(0.33 \times \mathrm{PB})+(0.143 \times \mathrm{NDF})\} ; \mathrm{ADICP}=\mathrm{acid}$ detergent insoluble crude protein, determined from the residue of the ADF. The NDFn and ADICO were determined starting from neutral and acid detergent insoluble nitrogen (LICITRA et al., 1996). 
Table 1 - Percentage composition of concentrate and chemical composition of diet ingredients.

\begin{tabular}{|c|c|c|c|c|c|c|c|c|}
\hline Items ( $\%$ dry matter $)$ & $\mathrm{CS}$ & FS & $\mathrm{STCH}$ & STCO & CGM & SM & MM & Urea \\
\hline Percentual composition & -- & -- & -- & -- & 60.00 & 34.50 & 5.00 & 0.50 \\
\hline Dry matter, \% & 31.70 & 27.68 & 27.33 & 27.69 & 88.03 & 87.41 & 99.98 & 99.98 \\
\hline Mineral matter & 4.45 & 5.08 & 5.26 & 5.21 & 2.12 & 6.99 & -- & -- \\
\hline Crude protein & 6.21 & 2.98 & 2.98 & 2.99 & 12.4 & 58.2 & -- & -- \\
\hline Ether extract & 3.50 & 2.01 & 2.01 & 2.02 & 5.35 & 3.14 & -- & -- \\
\hline Neutral detergent fiber & 54.04 & 49.37 & 51.90 & 52.01 & 4.09 & 11.9 & -- & -- \\
\hline Acid detergent fiber & 30.19 & 27.39 & 27.82 & 29.27 & 27 & 17.8 & -- & -- \\
\hline Acid detergent lignin & 3.56 & 6.18 & 5.16 & 5.06 & 1.27 & 1.8 & -- & -- \\
\hline Non fibrous carbohydrates & 31.80 & 40.56 & 37.85 & 37.33 & 53.13 & 13.87 & -- & -- \\
\hline Total carbohydrates & 85.84 & 89.93 & 89.75 & 89.34 & 80.13 & 31.67 & -- & -- \\
\hline Total digestible nutrients & 67.32 & 59.57 & 60.16 & 60.33 & 88.54 & 77.46 & -- & -- \\
\hline OMD & 74.52 & 68.80 & 69.55 & 69.69 & 92.06 & 89.47 & -- & -- \\
\hline NDFD & 57.60 & 47.18 & 51.34 & 51.72 & 61.39 & 43.60 & -- & -- \\
\hline
\end{tabular}

$\mathrm{CS}=$ corn silage; FS = fresh sugarcane; $\mathrm{STCH}=$ sugarcane treated with calcium hydroxide; $\mathrm{STCO}=$ sugarcane treated with calcium oxide; $\mathrm{CGM}=$ corn grain meal; $\mathrm{SM}=$ soybean meal; $\mathrm{MM}=$ mineral mixture $\left(\mathrm{Ca}=146 \mathrm{~g} \mathrm{~kg}^{-1} ; \mathrm{P}=60 \mathrm{~g} \mathrm{~kg}^{-1}\right) ; \mathrm{NM}=$ natural matter; OMD $=$ digestibility of organic matter; DNDF = digestibility of neutral detergent fiber.

Cows were milked twice-daily $(05 \mathrm{~h}$ and $14 \mathrm{~h}$ ), milk yield was individually obtained by measurers coupled to milking system. Milk yield was corrected to $4 \%$ fat $(4 \% \mathrm{FCMY})$ according $\mathrm{NRC}$ (2001), where: $4 \% \mathrm{FCMY}=\left(0.4 \mathrm{x} \mathrm{kgd}^{-1}\right.$ of milk $)+[15$ $\mathrm{x}$ (fat yield $\mathrm{x}$ milk yield/100)]. Milk composition was determined in samples proportional to daily milk yield collected on $17^{\text {th }}$ and $19^{\text {th }}$ days of each experimental period. These samples were refrigerated at $4^{\circ} \mathrm{C}$ in tubes containing 2-bromo-2-nitropropane-1-3diol at $2^{\circ} \mathrm{C}$ and analyzed at Clínica do Leite - Esalq/USP for protein, fat, lactose, total solids, and nonfat milk solids.

Data were subjected to analysis of variance and Pearson correlation, the means were compared by Tukey test $(\alpha=0.5)$, using the PROC MIXED of SAS statistical software (version 8.02). The mathematical model used was represented by: $\mathrm{Y}_{\mathrm{ijk}}=\mu+\mathrm{q}_{\mathrm{i}}+\mathrm{v}_{\mathrm{j}}\left(\mathrm{q}_{\mathrm{i}}\right)+\mathrm{p}_{\mathrm{k}}$ $\left(\mathrm{q}_{\mathrm{i}}\right)+\mathrm{t}_{1}+\left(\mathrm{t}_{1} \mathrm{q}_{\mathrm{i}}\right)+\mathrm{e}_{\mathrm{ijkl}}$, where $\mathrm{Y}_{\mathrm{ijkl}}=$ dependent variable; $\mu=$ general mean; $\mathrm{q}_{\mathrm{i}}=$ effect of square $\mathrm{i} ; \mathrm{v}_{\mathrm{j}}\left(\mathrm{q}_{\mathrm{i}}\right)=$ effect of cow j; $p_{k}\left(q_{i}\right)=$ effect of period $k ; t_{1}=$ effect of treatment $1 ;\left(\mathrm{t}_{1} \mathrm{q}_{\mathrm{i}}\right)=$ interaction between treatment 1 and square $\mathrm{i}$; $\mathrm{e}_{\mathrm{ijkl}}=$ experimental error.

\section{RESULTS AND DISCUSSION}

The effects of diets on dry matter intake and nutrients are shown in table 2 . The dry matter intake of cows fed with corn silage (CS) was 11.8 , 9.6 and $11 \%$ greater $(\mathrm{P}<0.05)$ than cows fed with fresh sugarcane (FS), sugarcane treated with calcium oxide (STCO) or hydroxide (STCH), respectively.
The DMI ( $\%$ of body weight) had similar behavior to DMI, expressed as $\mathrm{kg} / \mathrm{d}$, cows fed with CS had DMI $13.3,11.4$, and $11.4 \%$ higher $(\mathrm{P}<0.05)$ than cows fed with FS, STCO or STCH, respectively. These results demonstrated that the use of hydrolyzed sugarcane or not in the diet limited the DMI as function of the filling reticulum-rumen. This is due the high proportion of indigestible fiber of FS in relation to CS, which may represent $60 \%$ of the neutral detergent fiber (NDF) in the fresh sugarcane (FERNANDES et al., 2003), while in corn and sorghum silages, the indigestible portion of NDF is $28-33 \%$ (PIRES et al., 2010). The high content of indigestible fiber of FS compared to CS provides lower passage rate of the feed in the animal digestive tract, determining the physical limitation of consumption (ALLEN, 2000). According to MAGALHÃES et al. (2004), for every percentage point of FS replacing CS for lactating cows, DMI decreases $0.0266 \mathrm{~kg}$.

The presented results were similar to those obtained by MENDONÇA et al. (2004), which verified DMI 15\% higher for cows fed with diets containing $60 \%$ of CS in relation to diets with the same percentage of FS. CORRÊA et al. (2003) found lower difference $(6.52 \%)$ for DMI between diets with CS and FS, due to the use of higher amount of concentrate in the diet, stressing the rumen fill as a limiting factor to feed intake in fresh sugarcane based diets. It is noteworthy, moreover, that the treatment of sugarcane with lime did not cause changes in the palatability or acceptability of 
Table 2 - Nutrient intake by Holstein cows fed with different diet roughages.

\begin{tabular}{|c|c|c|c|c|c|c|}
\hline \multirow{2}{*}{ Items } & \multicolumn{4}{|c|}{ - } & \multirow{2}{*}{ CV $(\%)$} & \multirow{2}{*}{$\mathrm{P}$} \\
\hline & $\mathrm{CS}$ & FS & STCH & STCO & & \\
\hline Dry matter, $\mathrm{kg} \mathrm{d}^{-1}$ & $19.13^{\mathrm{a}}$ & $16.88^{\mathrm{b}}$ & $17.30^{\mathrm{b}}$ & $17.03^{\mathrm{b}}$ & 6.08 & 0.004 \\
\hline Dry matter, $\%$ body weight (BW) & $3.08^{\mathrm{a}}$ & $2.67^{\mathrm{b}}$ & $2.73^{\mathrm{b}}$ & $2.73^{\mathrm{b}}$ & 7.81 & 0.011 \\
\hline Crude protein, $\mathrm{kg} \mathrm{d}^{-1}$ & $2.78^{\mathrm{a}}$ & $2.34^{\mathrm{b}}$ & $2.35^{\mathrm{b}}$ & $2.34^{\mathrm{b}}$ & 3.18 & $<0.001$ \\
\hline Crude protein, $\% \mathrm{BW}$ & $0.44^{\mathrm{a}}$ & $0.37^{\mathrm{b}}$ & $0.37^{\mathrm{b}}$ & $0.37^{\mathrm{b}}$ & 5.08 & $<0.001$ \\
\hline Neutral detergent fiber, $\mathrm{kg} \mathrm{d}^{-1}$ & $6.22^{\mathrm{a}}$ & $4.38^{\mathrm{b}}$ & $5.05^{\mathrm{b}}$ & $4.76^{\mathrm{b}}$ & 15.76 & 0.001 \\
\hline Neutral detergent fiber, $\% \mathrm{BW}$ & $1.00^{\mathrm{a}}$ & $0.70^{\mathrm{b}}$ & $0.80^{\mathrm{b}}$ & $0.77^{\mathrm{b}}$ & 16.00 & 0.002 \\
\hline Total digestive nutrients, $\mathrm{kg} \mathrm{d}^{-1}$ & $13.72^{\mathrm{a}}$ & $11.62^{\mathrm{b}}$ & $11.92^{\mathrm{b}}$ & $11.76^{\mathrm{b}}$ & 5.80 & $<0.001$ \\
\hline Total digestive nutrients, $\% \mathrm{BW}$ & $2.21^{\mathrm{a}}$ & $1.84^{\mathrm{b}}$ & $1.88^{\mathrm{b}}$ & $1.89^{\mathrm{b}}$ & 7.42 & 0.001 \\
\hline
\end{tabular}

$\mathrm{CS}=$ diets containing corn silage; FS = diets containing fresh sugarcane; STCH = diets containing sugarcane treated with calcium hydroxide; $\mathrm{STCO}=$ diets containing sugarcane treated with calcium oxide; $\mathrm{CV}=$ coefficient of variation; $\mathrm{P}=$ statistical probability; means followed by different letters, in the row, differ by Tukey test $(\mathrm{P}<0.05)$.

the forage, fact supported by the feed intake, result contrary to that obtained by MISSIO et al. (2013). However, these results confirm those presented in the literature (CARVALHO et al., 2010; MISSIO et al., 2012) which, in most cases, there was no changes in feed intake by the addition of lime to sugarcane. Nevertheless, MISSIO et al. (2013) argue that when the treatment of sugarcane with lime increase the fiber digestibility it is expected higher feed intake in diets with hydrolyzed sugarcane in relation to those with fresh sugarcane.

The crude protein (CPI), neutral detergent fiber (NDFI) and total digestible nutrients (TDNI) intakes were higher $(\mathrm{P}<0.05)$ in diets with $\mathrm{CS}$ than those with FS, STCO and STCH (Table 2), exceeding the average of diets with sugarcane in $15.7,23.9$ and $14.2 \%$, respectively. However, the CPI, NDFI and TDNI did not differ among diets with FS, STCO and STCH. These variations in nutrient intake reflect the feed intake since the correlation coefficients of DMI with the CPI, NDFI and TDNI are $0.93 ; 0.85$ and 0.99 , respectively.

The results obtained in this study were similar to those observed by MISSIO et al. (2012), who found that the addition of $5 \mathrm{~g} \mathrm{~kg}^{-1}$ of $\mathrm{Ca}(\mathrm{OH})_{2}$ to sugarcane and stored for 24,48 or 72 hours did not change CPI, NDFI and TDNI. However, DIAS et al. (2011) evaluating amounts of $\mathrm{Ca}(\mathrm{OH})_{2}(0,8,16$ and $24 \mathrm{~g} \mathrm{~kg}^{-1}$ ) found higher point for CPI and NDFI for $8 \mathrm{~g} \mathrm{~kg}^{-1}$ of lime, due to increased digestibility of dry matter. MISSIO et al. (2013), on the other hand, found lower CPI, NDFI and TDNI for Nellore heifers fed with sugarcane treated with $5 \mathrm{~g} \mathrm{~kg}^{-1}$ $\mathrm{Ca}(\mathrm{OH})_{2}$, which was associated to the palatability and acceptability of hydrolyzed sugarcane by animals. For CS supplementation, results were similar to those observed by COSTA et al. (2005), who found CPI, NDFI and TDNI, 15.7, 21.1 and 9.9\% lower for FS based diets compared to CS, respectively.

Milk yield $\left(\mathrm{kg} \mathrm{d}^{-1}\right)$ was similar $(\mathrm{P}>0.05)$ between diets with $\mathrm{CS}$ and STCH (Table 3), and higher in diets with CS than those with FS and STCO. On the other hand, no difference was observed for milk yield between diets with FS, STCO and STCH. When corrected to $4 \%$ fat (4\% FCM), diets with hydrolyzed sugarcane determined similar milk yield in relation to the diets with CS and FS, while diets with FS had lower milk yield than those with $\mathrm{CS}$. Considering the variation in the body weight of the animals, it can be inferred that milk production was mainly determined by DMI and quality of diets, since, according to NRC (2001), the shift from one point of body condition score (scale from 1 to 5) is associated with variation of $80 \mathrm{~kg}$ body weight of the animals, excluding the possibility of producing milk maintained at the expense of mobilization of body fat in the diet with sugarcane.

These results showed that hydrolyzed sugarcane is a viable alternative feed and may be used as only forage in diet without compromising milk yield dairy cows of medium genetic potential. Furthermore, the addition of lime allowed greater flexibility in supply logistics, as it was used with 48 hours of storage, and reduced incidence of bees, corroborating the results obtained by MISSIO et al. (2012).

The similarity between the 4\% FCM from cows fed with hydrolyzed sugarcane and CS possibly reflected the good rumen conditions by the presence of alkaline agents, which promoted higher ruminal $\mathrm{pH}$, providing favorable conditions to cellulolytic bacteria growth, improving digestion, as verified by DIAS et al. (2011). In addition, the alkali agent 
Table 3 - Milk yield and composition of Holstein cows fed with different roughages.

\begin{tabular}{|c|c|c|c|c|c|c|}
\hline \multirow{2}{*}{ Items } & \multirow[b]{2}{*}{$\mathrm{CS}$} & \multirow[b]{2}{*}{ FS } & \multirow[b]{2}{*}{ STCH } & \multirow[b]{2}{*}{ STCO } & \multirow{2}{*}{ CV (\%) } & \multirow{2}{*}{$\mathrm{P}$} \\
\hline & & & & & & \\
\hline Body weight, $\mathrm{kg}$ & 634.62 & 641.25 & 644.37 & 632.12 & 1.96 & 0.409 \\
\hline Milk yield, $\mathrm{kg} \mathrm{d}^{-1}$ & $22.27^{\mathrm{a}}$ & $18.84^{\mathrm{b}}$ & $20.18^{\mathrm{ab}}$ & $19.98^{\mathrm{b}}$ & 7.38 & 0.005 \\
\hline Milk yield ${ }^{1}, \mathrm{~kg} \mathrm{~d}^{-1}$ & $20.05^{\mathrm{a}}$ & $17.33^{\mathrm{b}}$ & $17.89^{\mathrm{ab}}$ & $18.01^{\mathrm{ab}}$ & 8.51 & 0.022 \\
\hline Fat, \% & 3.32 & 3.48 & 3.22 & 3.23 & 9.74 & 0.399 \\
\hline Protein, \% & 3.14 & 3.13 & 3.06 & 3.06 & 3.02 & 0.184 \\
\hline Lactose, $\%$ & 4.14 & 4.12 & 4.19 & 4.09 & 3.48 & 0.570 \\
\hline Total solids, $\%$ & 11.48 & 11.55 & 11.31 & 11.22 & 3.81 & 0.447 \\
\hline Nonfat Milk solids, $\%$ & 8.17 & 8.14 & 8.09 & 8.00 & 2.47 & 0.382 \\
\hline
\end{tabular}

$\mathrm{CS}=$ diets containing corn silage; $\mathrm{FS}=$ diets containing fresh sugarcane; $\mathrm{STCH}=$ diets containing sugarcane treated with calcium hydroxide; STCO = sugarcane treated with calcium oxide; ${ }^{1} 4 \%$ fat-corrected milk; $\mathrm{CV}=$ coefficient of variation; $\mathrm{P}=$ statistical probability; means followed by different letters, in the row, differ by Tukey test $(\mathrm{P}<0.05)$.

acts on feed fiber increasing nutrients availability (soluble carbohydrates and lignin free structural carbohydrates), increasing fiber digestibility (PIRES et al., 2010; MISSIO et al., 2012), fact also detected in this study (Table 1).

Milk composition was not affected $(\mathrm{P}<0.05)$ by the bulky diets (Table 3 ), results are consistent with literature (MAGALHÃES et al., 2004; MENDONÇA et al., 2004; COSTA et al., 2005) since, in most cases, fat $(\mathrm{F})$, protein $(\mathrm{P})$, lactose $(\mathrm{L})$, total solids $(\mathrm{TS})$ and nonfat milk solids (NFMS) levels are not affected between CS and FS based diets. It is important to stress that F, P, L, TS and NFMS were similar to values recorded in the literature (MAGALHÃES et al, 2004; MENDONÇA et al., 2004; COSTA et al., 2005). Therefore, MENDONÇA et al. (2004) reported $3.8 ; 3.2 ; 9.1 ; 12.9$ and 3.9, 3.2, 9.0, 12.9 for F, P, TS, and NFMS and diets with $60 \%$ of CS and $50 \%$ of FS, respectively. COSTA et al. (2005) reported 3.6, 3.6, 4.1, 12.5 and 3.2; 3.7, 4.2, 12.2 of F, P, L and TS, for diets $60 \%$ of CS and $50 \%$ of FS, respectively.

\section{CONCLUSION}

The use of sugarcane treated with $\mathrm{Ca}(\mathrm{OH})_{2}$ is a viable option for feeding Holstein cows with average genetic potential for milk production, after lactation peak, because it allows production and composition similar to milk dairy cows fed with corn silage, besides benefiting the logistics of feeding in rural properties.

\section{BIOETHICS AND BIOSSECURITY COMMITTEE APPROVAL}

The animals were kept in good housing conditions and there was no discomfort to them. The authors take responsibility for any questioning about the future experiment. This way, considering the tales is the theunderstanding of the Editorial Board of this magazine for processing the article.

\section{ACKNOWLEDGEMENTS}

We thank the Fundação de Amparo à Pesquisa do Estado de São Paulo (FAPESP) by financial support.

\section{REFERENCES}

ALLEN, M.S. Effects of diet on short-term regulation of feed intake by lactating dairy cows. Journal of Dairy Science, v.83, n. 7 , p. $1598-1624,2000$

ALVES, A.C. do N. et al. Desempenho produtivo de vacas mestiças alimentadas com cana-de-açúcar hidrolisada e in natura. Nucleus Animalium, v.2, n.2, p.99-105, 2010. Available from: $<$ http://www.nucleus.feituverava.com.br/index. php/animalium/article/view/497>. Accessed: Apr. 09, 2014. doi: $10.3738 /$ na.v2i2.497.

ASSOCIATION OF OFFICIAL ANALYTICAL CHEMISTS (AOAC). Official methods of analysis. 16.ed. Arlington: AOAC International, 1995. 1025p.

CARVALHO, G.G.P. et al. Consumo e digestibilidade aparente em novilhas alimentadas com dietas contendo cana-de-açucar tratada com óxido de cálcio. Revista Brasileira de Zootecnia, v.39, n.12, p.2703-2713, 2010. Available from: $<$ http://www.scielo.br/pdf/rbz/ v39n12/a22v39n12.pdf>. Accessed: Oct. 18, 2013. doi: 10.1590/ S1516-35982010001200022.

CORRÊA, C.E.S. et al. Performance of Holstein cows fed sugar cane or corn silages of different grain textures. Scientia Agricola, v.60, n.4, p.621-629, 2003.

COSTA, M.G. et al. Desempenho produtivo de vacas leiteiras alimentadas com diferentes proporções de cana-de-açúcar e concentrado ou silagem de milho na dieta. Revista brasileira de Zootecnia, v.34, n.6, p.2437-2445, 2005. (supl.). Available from: $<$ http://www.scielo.br/pdf/rbz/v34n6s0/a32v3460.pdf $>$. Accessed: Oct. 17, 2013. doi: 10.1590/S1516-35982005000700032. 
DIAS, A.M. et al. Sugar cane treated with calcium hydroxide in diet for cattle: intake, digestibility of nutrients and ingestive behavior. Revista Brasileira de Zootecnia, v.40, n.8, p.17991806, 2011. Available from: <http://www.scielo.br/pdf/rbz/ v40n8/25.pdf>. Accessed: Oct. 17, 2013. doi: 10.1590/S151635982011000800025

DOMINGUES, F.N. et al. Estabilidade aeróbia, pH e dinâmica de desenvolvimento de microrganismos da cana-de-açúcar in natura hidrolisada com cal virgem. Revista Brasileira de Zootecnia, v.40, n.4, p.715-719, 2011. Available from: $<$ http://www.scielo. br/pdf/rbz/v40n4/03.pdf >. Accessed: Oct. 18, 2013. doi: 10.1590/ S1516-35982011000400003

FERNANDES, A.M. et al. Composição químico-bromatológica de variedades de cana-de-açúcar (Saccharum spp.L.) com diferentes ciclos de produção (precoce e intermediário) em três idades de colheita. Revista Brasileira de Zootecnia, v.32, n.4 p.977-985, 2003.

LICITRA, G. et al. Standardization of procedures for nitrogen fractionation of ruminant feeds. Animal Feed Science and Technology, v.56, [s.n], p.347-358, 1996

MAGALHÃES, A.L.R. et al. Cana-de-açúcar em substituição à silagem de milho em dietas para vacas em lactação: desempenho e viabilidade econômica. Revista Brasileira de Zootecnia, v.33, n.5, p.1292-1302, 2004. Available from: <http://www.scielo.br/ pdf/rbz/v33n5/a22v33n5.pdf>. Accessed: Oct. 17, 2013. doi: $10.1590 / \mathrm{S} 1516-35982004000500022$

MENDONÇA, S.S. et al. Consumo, digestibilidade aparente, produção e composição do leite e variáveis ruminais em vacas leiteiras alimentadas com dietas à base de cana-de-açúcar. Revista Brasileira de Zootecnia, v.33, n.2, p.481-492, 2004. Available from: <http://www.scielo.br/pdf/rbz/v33n2/21263.pdf>. Accessed: Oct. 17, 2013. doi: 10.1590/S1516-35982004000200027.

MISSIO, R.L. et al. Consumo de matéria seca e desempenho de novilhas Nelore alimentadas com dietas contendo cana-deaçúcar hidrolisada. Ciência Rural, v.43, n.6, p.1050-1056, 2013. Available from: <http://www.scielo.br/pdf/cr/2013nahead/ a16713cr2012-0591.pdf>. Accessed: Oct. 17, 2013. doi: 10.1590/ S0103-84782013005000069.

MISSIO, R.L. et al. Characteristics of forage and feeding behavior of Nellore heifers fed with hydrolyzed sugarcane. Revista Brasileira de Zootecnia, v.41, n.9, p.2092-2100, 2012. Available from: <http://www.scielo.br/pdf/rbz/v41n7/25.pdf $>$. Accessed: Sept. 28, 2013b. doi: 10.1590/ S1516-35982012000900018.

NATIONALRESEARCHCOUNCIL(NRC). Nutrient requirements of dairy cattle. 7.ed. rev. Washington, D.C., 2001. 381p.

OLIVEIRA, M.D.S. Cana-de-açúcar hidrolisada na alimentação de bovinos - Técnica da hidrólise com cal virgem ou hidratada. Jaboticabal: FUNEP, 2010. 116p.

PIRES, A.J.V. et al. Chemical treatment of roughage. Revista Brasileira de Zootecnia, v.39, p.192-203, 2010. (Supl esp.). Available from: <http://www.scielo.br/pdf/rbz/v39sspe/22.pdf $>$. Accessed: Oct. 18, 2013. doi: 10.1590/S1516- 35982010001300022.

PIRES, A.J.V. et al. Degradabilidade ruminal da matéria seca, da proteína bruta e da fração fibrosa de silagens de milho, sorgo e de Brachiaria brizantha. Arquivo Brasileiro de Medicina Veterinária e Zootecnia, v.62, n.2, p.391-400, 2010. Available from: <http://www.scielo.br/pdf/abmvz/v62n2/20.pdf >. Accessed: Oct. 17, 2013. doi: 10.1590/S0102-09352010000200020.

SNIFFEN, C.J. et al. A new carbohydrate and protein system for evaluating cattle diets. II. Carbohydrate and protein availability. Journal of Animal Science, v.70, n. 12, p.3562-3577, 1992.

VAN SOEST, P.J. Collaborative study of acid detergent fiber and lignin. Journal of the Association of Official Analytical Chemists, v.56, p.81-784, 1973.

VAN SOEST, P.J. et al. Methods for dietary fiber, neutral detergent fiber, and nonstarch polysaccharides in relation to animal nutrition, Journal of dairy Science, v.74, p.3583-3597, 1991.

WEISS, W.P. Method estimates available energy value for ruminants. Feedstuffs, v.9, p.13-14, 1993 